\title{
昼夜温度差および短時間変温がシネンシス系デルフィニウムの生育に及ぼす影響
}

\author{
佐々木和也 ${ }^{1,2} *$ ・西島隆明 ${ }^{3} \cdot$ 本多和茂 ${ }^{1,4}$ •嵯峨紘一 ${ }^{1,4}$ •鮫島正純 ${ }^{1,4}$ \\ 1 岩手大学大学院連合農学研究科 $020-8550$ 盛岡市上田三丁目 18-8 \\ 2 青森県農林総合研究センター フラワーセンター 21 あ扣もり 030-0134 青森市合子沢松森 395-1 \\ 3 農業・食品産業技術総合研究機構 花き研究所 305-8519 つくば市藤本 2-1 \\ 4 弘前大学農学生命科学部 $036-8560$ 弘前市文京町 3
}

\section{Effects of Difference between Day and Night Temperature and Short Time Temperature Fluctuations on the Growth of Delphinium grandiflorum L.}

\author{
Kazuya Sasaki ${ }^{1,2 *}$, Takaaki Nishijima ${ }^{3}$, Kazushige Honda ${ }^{1,4}$, Koichi Saga $^{1,4}$ and Masazumi Sameshima ${ }^{1,4}$ \\ ${ }^{I}$ The United Graduate School of Agricultural Sciences, Iwate University, Morioka 020-8550 \\ ${ }^{2}$ Ornamentals Experiment Station, Aomori Prefectural Agriculture and Forestry Research Center, Aomori 030-0134 \\ ${ }^{3}$ National Institute of Floricultural Science, National Agriculture and Food Research Organization, Tsukuba 305-8519 \\ ${ }^{4}$ Faculty of Agriculture and Life Science, Hirosaki University, Hirosaki 036-8560
}

\begin{abstract}
The effects of DIF (difference between day and night temperature), TD (short time temperature drop) and TR (short time temperature rising) on the growth of Delphinium grandiflorum L. cv. 'Blue Mirror' were investigated. Minus DIF $\left(15^{\circ} \mathrm{C}\right.$ and $25^{\circ} \mathrm{C}$ during the light and dark period, respectively) decreased the plant height by $42 \%$ to $49 \%$ compared to that of plants treated with plus DIF $\left(25^{\circ} \mathrm{C}\right.$ and $15^{\circ} \mathrm{C}$ during the light and dark period, respectively). TD down to $10^{\circ} \mathrm{C}$ for 4 hours started 2 hours before the end of the dark, did not influence the plant height. On the other hand, TR up to $30^{\circ} \mathrm{C}$ for 4 hours at the beginning of the dark period, decreased the height by $22 \%$ to $33 \%$ compared to that of + DIF. Both length and width of stem pith cells in the plants treated with - DIF, were decreased by about $20 \%$ compared to those of + DIF. Plants - DIF showed a decrease in the relative number of pith cells in the vertical direction by $26 \%$ compared to that of plants + DIF, although the number in the horizontal direction were decreased by only $5 \%$. Endogenous gibberellins, $\mathrm{GA}_{9}$ and $\mathrm{GA}_{24}$, were identified in the shoot of $D$. grandiflorum. The concentration of $\mathrm{GA}_{24}$ was lower in -DIF than in $+\mathrm{DIF}$, indicating that DIF regulated the stem elongation through biosynthesis of gibberellin.
\end{abstract}

Key Words : cell number, cell size, diurnal temperature alternation, gibberellin, stem elongation キーワード : ジベレリン, 茥伸長, 日周温度, 細胞の大きさ, 細胞数

\begin{abstract}
緒言
デルフィニウムは, 1850 年頃からヨーロッパの花壇で 利用され, 近年, 日本でも生産が増加している（勝谷・池 田，1997）が，一般的に大型植物である. 花きは鉢物や花 壇で利用される場合, 流通性や消費者の嗜好の面から小型 のものが望まれていることから，デルフィニウムを鉢物用 に供するためには，草丈の短縮が必要である．茥伸長の抑 制については，昼温よりも夜温を高く設定する負の昼夜温 度差 (-DIF) や, 昼夜温に打ける一時的降温, 昇温処理に よる短時間変温の有効性が, カンパニュラ（Moe, 1990; Moe・Heins, 1990; Moe ら, 1991) , フクシア (Erwin ら, 1991), キク (Karlsson ら, 1989), テッポウユリ（Berghage
\end{abstract}

2006 年 11 月 6 日 受付. 2007 年 2 月 26 日 受理.

*Corresponding author. E-mail: kazuya_sasaki@pref.aomori.lg.jp
ら，1990; Erwin ら，1994）などで報告されている. これに は内生ジベレリン（GA）の関与が示唆されている（Jensen ら, 1996; Nishijima ら, 1997).

本研究では, DIF および短時間変温がシネンシス系デル フィニウムの生育に及ぼす影響について調査した．DIF に よる茎伸長抑制の作用機作について明らかにするため, 組 織細胞形態の変化および内生 GA 代謝との関連を調査した. さらに日周温度による草丈調節の実用化を目的として，短 時間変温の影響を検討した。

\section{材料および方法}

\section{1. 供試材料および栽培方法}

供試材料として, シネンシス系デルフィニウム (Delphinium grandiflorum L.) の ‘ブルーミラー’を用いた. 処理開始まで, 最低温度 $15^{\circ} \mathrm{C}$, 換気温度 $23^{\circ} \mathrm{C}$ に制御した 
A

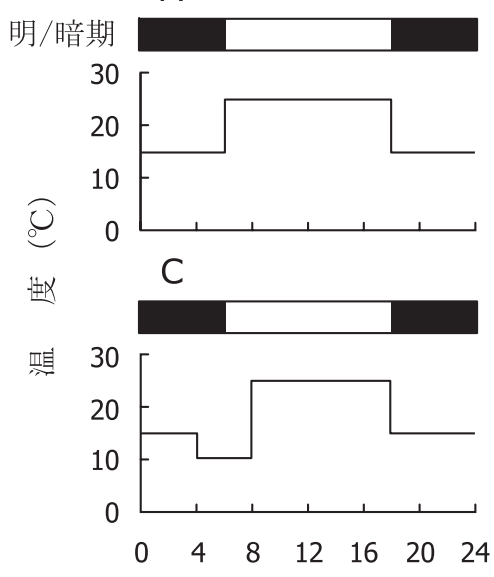

B
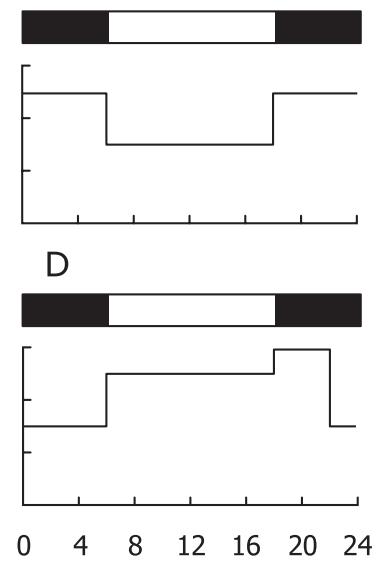

時刻 (時)

第 1 図 昼夜温度差および短時間変温処理の温度と日長の設定条件

A : +DIF（昼温 $25^{\circ} \mathrm{C} /$ 夜温 $15^{\circ} \mathrm{C}$ ), B : - DIF (昼温 $15^{\circ} \mathrm{C} /$ 夜温 $25^{\circ} \mathrm{C}$ )

$\mathrm{C}: \mathrm{TD}$ (短時間降温; 昼温 $10^{\circ} \mathrm{C} \rightarrow 25^{\circ} \mathrm{C} /$ 夜温 $15^{\circ} \mathrm{C} \rightarrow 10^{\circ} \mathrm{C}$ )

$\mathrm{D}: \mathrm{TR}$ (短時間昇温; 昼温 $25^{\circ} \mathrm{C} /$ 夜温 $30^{\circ} \mathrm{C} \rightarrow 15^{\circ} \mathrm{C}$ )

$\square$ : 暗期 (18 時〜 6 時)， $\square$ : 明期（6 時〜 18 時）

ガラス温室内で栽培した. 種子を 128 穴セルトレイに播き, 播種 8 週後に実生苗を 3 号ポリポットへ移植した. 播種用 土にはげんきくん 2 号 (全農) を，鉢上げ用土には基肥を $\mathrm{N}: \mathrm{P}_{2} \mathrm{O}_{5}: \mathrm{K}_{2} \mathrm{O}=420: 360: 420 \mathrm{mg} \cdot \mathrm{L}^{-1}$ の割合で加えた黒ボ ク土主体のものを，それぞれ用いた。

\section{DIF および短時間降温（TD）}

試験には， 3 生育ステージの植物を用いた。 2005 年 3 月 2 日，3 月 31 日扎よび 4 月 28 日に播種し，それぞれについ て 5 月 25 日から温度処理を開始した. この時点で, 平均葉 齢はそれぞれ 8.4，4.4 および 1.3 枚であり，3 月 2 日播種 のものだけが抽苔し始めていた，処理には人工気象室 （KG-50HLA，小系工業株式会社）を使用し，白色蛍光灯 (約 $140 \mu \mathrm{mol} ・ \mathrm{~m}^{-2} \cdot \mathrm{s}^{-1}$ ) で照明した. 全ての実験において 明期を 6 時〜 18 時，暗期を 18 時〜 6 時に設定した.

処理区の設定温度を, +DIF では明期 $25^{\circ} \mathrm{C}$ および暗期 $15^{\circ} \mathrm{C}$ (第 1 図 A）, -DIF では明期 $15^{\circ} \mathrm{C}$ および暗期 $25^{\circ} \mathrm{C}$ (第 1 図 B), TD では 4 時〜 8 時を $10^{\circ} \mathrm{C}, 8$ 時〜 18 時を $25^{\circ} \mathrm{C}$, 18 時〜 4 時を $15^{\circ} \mathrm{C}$ とした（第 1 図 C）. 各処理区当たり 20 個体を供試した。処理後, 抽苔日, 播種から抽苔までの 日数 (以下, 抽苔日数), 開花日, 播種から開花までの日数 (以下, 到花日数) 抒よび開花時の形態的特徴（草丈, 主花 穂長, 主花穂の小花数, 長さ $1 \mathrm{~cm}$ 以上の側枝数) を調査し た. 抽苔日は目視により節間伸長が確認できた時点, 開花 日は主花穂の小花が 1 輪以上開花した時点とした.

\section{3. 短時間昇温 (TR)}

2005 年 4 月 28 日打よび 5 月 12 日に播種し, 6 月 17 日か ら温度処理を開始した．この時点で，平均葉齢は 6.7 およ び 3.5 枚であり，いずれも未抽苔であった．処理には人工 気象器（LIB-302H, 旭テクノグラス株式会社）を使用し,
白色蛍光灯（約 $90 \mu \mathrm{mol} ・ \mathrm{~m}^{-2} ・ \mathrm{~s}^{-1}$ ） で照明した．TRの設 定温度は, 6 時〜 18 時を $25^{\circ} \mathrm{C}, 18$ 時〜 22 時を $30^{\circ} \mathrm{C}, 22$ 時〜 6 時を $15^{\circ} \mathrm{C}$ とした（第 1 図 D）。生育調査は，上記 2 と同様に行った.

\section{4. 茎組織における髄細胞の大きさおよび数}

DIF による茎伸長量の差異が，細胞の大きさと数のいず れに起因するのかを明らかにするため，髄細胞の大きさと 数を調査した.

材料には，上記 2 で供試した 3 月 31 日に播種し，5 月 25 日にDIF 処理した開花時の植物体を用いた．DIF による茥 伸長の差異が最も顕著に現れた第 13 節〜 14 節目の節間を 採取し，節間長および直径を測定した後に，ホルマリン： 酢酸：エタノール: 水 $=1: 1: 9: 9(\mathrm{v} / \mathrm{v})$ の混合溶液で固 定し， $4^{\circ} \mathrm{C}$ で保存した。節間の中央部を約 $5 \mathrm{~mm}$ の長さで 切断した後, 5\%寒天に包埋し，マイクロスライサーで作成 した $45 \mu \mathrm{m}$ 厚の切片をアニリンブルーで染色し, 光学顕微 鏡下で観察した。横断切片の観察から，細胞の大きさがほ ぼ均一な維管束組織より内側を髄組織と判定し, この直径 を計測した（第 2 図 A, B). 髄細胞は茥の伸長方向，つま り垂直方向に沿って細長い形態をしているため, 細胞の長 径扣よび短径についてもそれぞれ縦断切片像上で測定した (第 2 図 C, D).

節間内部の髄組織における細胞数は，茎の垂直および水 平方向で異なるため, 垂直方向に拈いては髄組織の平均長 を細胞の平均長径で，水平方向に打いては髄組織の平均直 径を細胞の平均短径でそれぞれ除した值とした。DIF 処理 した植物体のこの值を比較することにより，髄における細 胞数の相対的な差異を解析した。 


\section{5. 内生 GA の同定と定量}

内生 GA の定性分析のために 2004 年 11 月 10 日に播種 し, 2005 年 4 月 26 日から 6 月 7 日にかけて, 約 $10 \mathrm{~cm}$ に 伸びたシュートの茥頂組織を含む茎先端部約 $5 \mathrm{~cm}$ を採取 した. 新鮮重約 $250 \mathrm{~g}$ の試料を, $80 \%$ メタノールに浸漬し た状態で, GA 分析の開始時まで暗黒下, $4^{\circ} \mathrm{C} て ゙$ 保存した.

DIF が内生 GA 濃度に及ぼす影響を調査するために, 2005 年 9 月 15 日に播種し, ほとんどの個体が抽苔した 2006 年 1 月 17 日に + DIF（第 1 図 A）と-DIF（第 1 図 B ) の温度処理を開始した. 処理には人工気象室（小糸工業株 式会社）を使用し，光条件は上記 2 と同様とした，処理開 始時，2 週後抢よび 5 週後に，それぞれ新鮮重約 $40 \mathrm{~g}$ の茥 先端部を上述と同様に採取し，保存した。

GA 分析は, 簡易微量検定法と常法による精製・分離体 系（西島，2000）に基づき行った. 茥先端部抽出液を逆相 分配カラム（ODS）を用いた高速液体クロマトグラフ
（HPLC）により 30 画分に分離した。この中から GA 活性が 認められた画分をイオン交換カラム $\left(\mathrm{N}\left(\mathrm{CH}_{3}\right)_{2}\right)$ を用いた HPLC により 8 画分に分離した.さらに, GA 活性が認めら れた試料をガスクロマトグラフ質量分析計 (GC/MS, ヒューレット・パッカード株式会社）で分析した. ジベレ リンの同定は, GC/MS によって得られたマススペクトルの 各々のイオン強度の相対值と KRI (Kovat's Retention Index) を GA 標品と比較することにより行った.

\section{結 果}

\section{1. +DIF，-DIF および TD が生育に及ぼす影響}

葉齢 4.4 枚区および葉齢 1.3 枚区では, 抽苔日数は+DIF で短く, -DIF で長くなり，両者間差は有意であり，TD で はその中間であった（第 1 表）。葉齢 8.4 枚においては，処 理間に差異が認められなかった。

到花日数は, 葉齢 4.4 枚区のみで有意差が認められ, 抽

第 1 表 DIF 抒よびTD がシネンシス系デルフィニウムの抽苔，開花拉よび開花時の形態に及ぼす影響

\begin{tabular}{|c|c|c|c|c|c|c|c|c|}
\hline \multirow{2}{*}{$\begin{array}{l}\text { 処理葉齢 } \\
\text { 処理区 }^{\mathrm{y}}\end{array}$} & \multirow{2}{*}{$\begin{array}{l}\text { 抽苔日 } \\
\text { (月／日） }\end{array}$} & \multirow[b]{2}{*}{ 抽苔日数 } & \multirow{2}{*}{$\begin{array}{l}\text { 開花日 } \\
\text { (月／日） }\end{array}$} & \multirow[b]{2}{*}{ 到花日数 } & \multicolumn{4}{|c|}{ 開花時の形態 } \\
\hline & & & & & $\begin{array}{l}\text { 草丈 } \\
(\mathrm{cm})\end{array}$ & $\begin{array}{l}\text { 主花穂長 } \\
(\mathrm{cm})\end{array}$ & $\begin{array}{c}\text { 主花穂の } \\
\text { 小花数（個） }\end{array}$ & $\begin{array}{l}\text { 側枝数 } \\
\text { (本) }\end{array}$ \\
\hline \multicolumn{9}{|l|}{ 葉齢 8.4 枚 } \\
\hline+ DIF & $6 / 1$ & $91.3 \mathrm{a}^{\mathrm{x}}$ & $7 / 9$ & $129.9 \mathrm{a}$ & $50.9 \mathrm{a}$ & $12.8 \mathrm{a}$ & $8.1 \mathrm{a}$ & $4.3 \mathrm{a}$ \\
\hline- DIF & $6 / 5$ & $95.3 \mathrm{a}$ & $7 / 14$ & $134.4 \mathrm{a}$ & $29.7 \mathrm{~b}$ & $7.9 \mathrm{~b}$ & $7.3 \mathrm{a}$ & $3.3 \mathrm{a}$ \\
\hline TD & $6 / 3$ & $93.5 \mathrm{a}$ & $7 / 14$ & $134.2 \mathrm{a}$ & $50.0 \mathrm{a}$ & $12.2 \mathrm{a}$ & $7.0 \mathrm{a}$ & $3.8 \mathrm{a}$ \\
\hline \multicolumn{9}{|l|}{ 葉齢 4.4 枚 } \\
\hline $\begin{array}{l}+\mathrm{DIF} \\
+x^{2}\end{array}$ & $6 / 19$ & $80.1 \mathrm{~b}$ & $7 / 30$ & $121.0 \mathrm{~b}$ & $67.6 \mathrm{a}$ & $16.9 \mathrm{a}$ & $7.8 \mathrm{a}$ & $4.0 \mathrm{a}$ \\
\hline$-\mathrm{DIF}$ & $7 / 12$ & $103.0 \mathrm{a}$ & $8 / 20$ & $142.0 \mathrm{a}$ & $34.3 \mathrm{~b}$ & $9.8 \mathrm{~b}$ & $5.7 \mathrm{~b}$ & $3.5 \mathrm{a}$ \\
\hline $\mathrm{TD}$ & $6 / 29$ & $90.7 \mathrm{ab}$ & $8 / 11$ & $133.4 \mathrm{ab}$ & $62.0 \mathrm{a}$ & $14.7 \mathrm{a}$ & $7.7 \mathrm{a}$ & $4.1 \mathrm{a}$ \\
\hline \multicolumn{9}{|l|}{ 葉齢 1.3 枚 } \\
\hline$+\mathrm{DIF}$ & $6 / 29$ & $62.9 \mathrm{~b}$ & $8 / 10$ & $104.1 \mathrm{a}$ & $56.7 \mathrm{a}$ & $13.7 \mathrm{a}$ & $8.1 \mathrm{a}$ & $4.2 \mathrm{a}$ \\
\hline$-\mathrm{DIF}$ & $7 / 10$ & $73.2 \mathrm{a}$ & $8 / 19$ & $113.6 \mathrm{a}$ & $31.1 \mathrm{~b}$ & $8.8 \mathrm{~b}$ & $5.5 \mathrm{~b}$ & $2.8 \mathrm{~b}$ \\
\hline TD & $7 / 2$ & $65.8 \mathrm{ab}$ & $8 / 15$ & $109.2 \mathrm{a}$ & $66.1 \mathrm{a}$ & $17.3 \mathrm{a}$ & $9.1 \mathrm{a}$ & $4.0 \mathrm{ab}$ \\
\hline
\end{tabular}

$\mathrm{z}$ 葉齢 8.4 枚は 2005 年 3 月 2 日，葉齢 4.4 枚は 3 月 31 日抢よび葉齢 1.3 枚は 4 月 28 日に播種， 5 月 25 日から処理を開始 $\mathrm{y}+\mathrm{DIF},-\mathrm{DIF}$ 打よび TD の処理条件は第 1 図を参照

$\mathrm{x}$ 欄内の值は平均值を示し，同一葉齢内の異なるアルファベット間には Tukey 法により，1\%水準で有意差あり

第 2 表 TR がシネンシス系デルフィニウムの抽苔, 開花および開花時の形態に及ぼす影響

\begin{tabular}{|c|c|c|c|c|c|c|c|c|}
\hline \multirow{2}{*}{$\begin{array}{l}\text { 処理葉齢 }{ }^{z} \\
\text { 処理区 }^{y}\end{array}$} & \multirow[b]{2}{*}{$\begin{array}{l}\text { 抽苔日 } \\
\text { (月／日） }\end{array}$} & \multirow[b]{2}{*}{ 抽苔日数 } & \multirow[b]{2}{*}{$\begin{array}{l}\text { 開花日 } \\
\text { (月／日） }\end{array}$} & \multirow[b]{2}{*}{ 到花日数 } & \multicolumn{4}{|c|}{ 開花時の形態 } \\
\hline & & & & & $\begin{array}{l}\text { 草丈 } \\
(\mathrm{cm})\end{array}$ & $\begin{array}{l}\text { 主花穂長 } \\
(\mathrm{cm})\end{array}$ & $\begin{array}{c}\text { 主花穂の } \\
\text { 小花数（個） }\end{array}$ & $\begin{array}{l}\text { 側枝数 } \\
\text { (本) }\end{array}$ \\
\hline \multicolumn{9}{|l|}{ 葉齢 6.7 枚 } \\
\hline+ DIF & $7 / 18^{x}$ & 81.6 & $8 / 24$ & 118.5 & 51.8 & 14.2 & 6.7 & 2.9 \\
\hline TR & $7 / 22$ & 85.1 & $8 / 25$ & 119.5 & 40.5 & 11.4 & 6.1 & 3.7 \\
\hline 有意差 ${ }^{w}$ & - & ns & - & $\mathrm{ns}$ & $* *$ & ns & ns & $\mathrm{ns}$ \\
\hline \multicolumn{9}{|l|}{ 葉齢 3.5 枚 } \\
\hline+ DIF & $8 / 21$ & 101.6 & $9 / 27$ & 138.1 & 56.8 & 18.5 & 7.2 & 4.4 \\
\hline TR & $8 / 26$ & 106.8 & $9 / 30$ & 141.3 & 38.2 & 12.2 & 6.3 & 3.7 \\
\hline 有意差 & - & $\mathrm{ns}$ & - & $\mathrm{ns}$ & $* *$ & $* *$ & ns & ns \\
\hline
\end{tabular}

z 葉齢 6.7 枚は 2005 年 4 月 28 日, 葉齢 3.5 枚は 5 月 12 日に播種, 7 月 6 日から処理を開始

${ }^{\mathrm{y}}+\mathrm{DIF}$ と TR の処理条件は第 1 図を参照

$\mathrm{x}$ 欄内の值は平均値を示す

${ }^{\mathrm{w}} t$ 検定により，同一葉齢内で**は $1 \%$ 水準で有意差あり，ns は有意差なし，一は分析なし 
苔日数と同様に, +DIF で短く, -DIF で長くなり, TD では その中間であった。

開花時の草丈は, いずれの葉齢においても+DIF と TD で は差異が認められず，-DIF では+DIF に比べ $42 \sim 49 \%$ 短縮した. 開花時の主花穂長も同様で, いずれの葉齢にお いても-DIFで，+DIF およびTD と比較して有意に短縮し た. 主花穂の小花数は葉齢 1.3 枚区および葉齢 4.4 枚区で, 側枝数は葉齢 1.3 枚区で，そ秃ぞれ-DIF と扔いて+DIF お よび TD と比較して減少した.

\section{TR が生育に及ぼす影響}

抽苔および到花日数には TR と+DIF の差異は見られな かった (第 2 表).

開花時の草丈は, いずれの葉齢においても, TR では+DIF に比べ $22 \sim 33 \%$ と有意に短縮した. 主花穂長は, 葉齢 3.5 枚区の TR では+DIF に比べ短縮したが, 葉齢 6.7 枚区では 差異が見られなかった. いずれの葉齢に扔いても, +DIF と $\mathrm{TR}$ との間に, 主花穂の小花数と側枝数の差異は見られな かった.

\section{3. -DIF による茎伸長量の減少と細胞の大きさおよび数と の関連}

節間長と直径の平均は, + DIF で $10.14 \mathrm{~cm}$ と $2.50 \mathrm{~mm}$ で あった (第 3 表).一方, -DIF では $5.92 \mathrm{~cm}$ と $1.87 \mathrm{~mm}$ で あり，そ秃沓孔+DIF に比較して $42 \%$ と $25 \%$ 減少してい た. 䯣組織の直径は+DIF で $1.13 \mathrm{~mm},-$ DIF で $0.84 \mathrm{~mm}$ で あり, 減少率は節間の直径とほぼ同一の 26\%であった。

髄細胞の長径と短径は, +DIF でそれぞれ $441 \mu \mathrm{m}$ と $67.1 \mu \mathrm{m},-$ DIF で $348 \mu \mathrm{m}$ と $52.5 \mu \mathrm{m}$ であった（第 3 表，第 2 図)。このように-DIF では+DIF に比較し, 䯣細胞の長径 と短径は同様の減少率を示し，それぞれ $21 \%$ および $22 \%$ の減少であった，一方，䯣細胞の数は，+DIF では垂直方向 で 230 個拈よび水平方向で 16.8 個であり, -DIF ではそれ ぞれ 170 個抢よび 16.0 個であった。 寸なわち，-DIF 処理

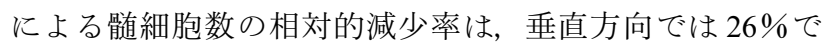
あったのに対し, 水平方向の減少はわずか $5 \%$ であった.

\section{4. 内生 GA とその濃度に及ぼす DIF の影響}

シュートから $\mathrm{GA}_{9}$ と $\mathrm{GA}_{24}$ が内生 $\mathrm{GA}$ として同定された

第 3 表 DIF がシネンシス系デルフィニウムの茥の髄細胞の大きさと数に及ぼす影響

\begin{tabular}{|c|c|c|c|c|c|c|c|c|}
\hline \multirow[b]{2}{*}{ 処理区 ${ }^{\mathrm{z}}$} & \multicolumn{2}{|c|}{ 節間 } & \multicolumn{2}{|c|}{ 髄組織 } & \multicolumn{2}{|c|}{ 髄細胞の大きさy } & \multicolumn{2}{|c|}{ 骨迶細胞の数 } \\
\hline & $\begin{array}{l}\text { 長さ } \\
(\mathrm{cm})\end{array}$ & $\begin{array}{l}\text { 直径 } \\
(\mathrm{mm})\end{array}$ & $\begin{array}{l}\text { 長さ } \\
(\mathrm{mm})\end{array}$ & $\begin{array}{l}\text { 直径 } \\
(\mathrm{mm})\end{array}$ & $\begin{array}{l}\text { 長径 } \\
(\mu \mathrm{m})\end{array}$ & $\begin{array}{l}\text { 短径 } \\
(\mu \mathrm{m})\end{array}$ & 垂直方向 & 水平方向 \\
\hline +DIF (A) & $10.14^{x}$ & 2.50 & 101.4 & 1.13 & 441 & 67.1 & 230 & 16.8 \\
\hline -DIF（B） & 5.92 & 1.87 & 59.2 & 0.84 & 348 & 52.5 & 170 & 16.0 \\
\hline 有意差 ${ }^{w}$ & $* *$ & $* *$ & $* *$ & $* *$ & $*$ & $* *$ & - & - \\
\hline 減少率 $(\%)^{\mathrm{v}}$ & 42 & 25 & 42 & 26 & 21 & 22 & 26 & 5 \\
\hline
\end{tabular}

${ }^{\mathrm{z}}+\mathrm{DIF}$ と-DIF の処理条件は第 1 図を参照

${ }^{\mathrm{y}}$ 長径 : 垂直方向の髄細胞長, 短径 : 水平方向の髄細胞長

$\mathrm{x}$ 欄内の值は平均值を示す

${ }^{\mathrm{w}} t$ 検定により，*は5\%, **は $1 \%$ の水準で有意差あり，一は分析なし

v減少率 $(\%)$ は $(\mathrm{A}-\mathrm{B}) / \mathrm{A} \times 100$ の計算式により求めた
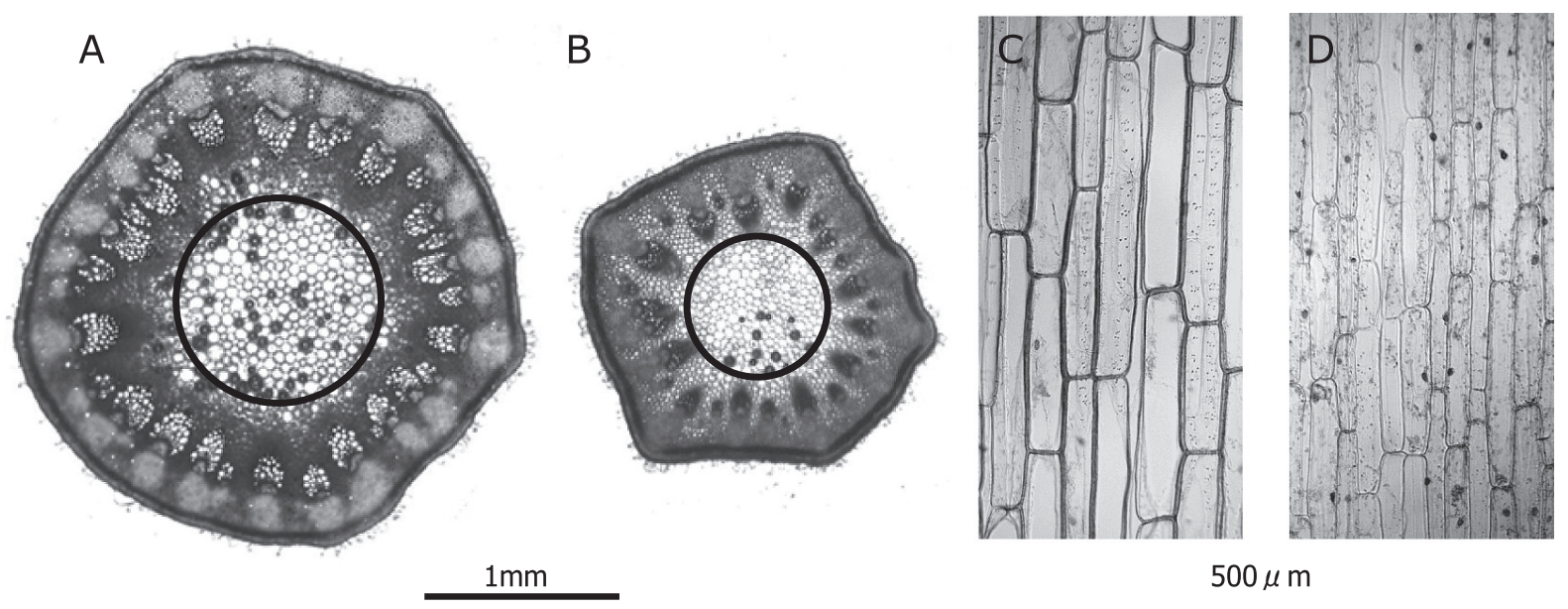

第 2 図 DIF によるシネンシス系デルフィニウムの茥組織の変化

A : +DIF で栽培した植物の茎組織の横断面, B : -DIF で栽培した植物の茎組織の横断面 C : +DIF で栽培した植物の䯣組織の縦断面, D : -DIF で栽培した植物の䯣組織の縦断面 実線内：測定した䯣組織の部分, 処理条件は第 1 図を参照 
第 4 表 シネンシス系デルフィニウムのシュートから同定された内生 GA

\begin{tabular}{|c|c|c|c|}
\hline GA & $\begin{array}{l}\text { ODS-HPLC } \\
\text { 画分の番号 }\end{array}$ & $\mathrm{KRI}^{\mathrm{z}}$ & $\begin{array}{c}\text { 主要なイオンとイオン強度 } \\
\text { (ベースピークのイオン強度を } 100 \% \text { とした相対值) }\end{array}$ \\
\hline $\mathrm{GA}_{9}$ & $19-23$ & 2337 & $330(5), \quad 298(86), \quad 270(100), \quad 243(68), \quad 226(74)$ \\
\hline $\mathrm{GA}_{24}$ & $19-23$ & 2483 & $374(4), 342(21), \quad 314(100), \quad 286(4), \quad 254$ (18) \\
\hline
\end{tabular}

${ }^{\mathrm{z}}$ Kovat's Retention Index

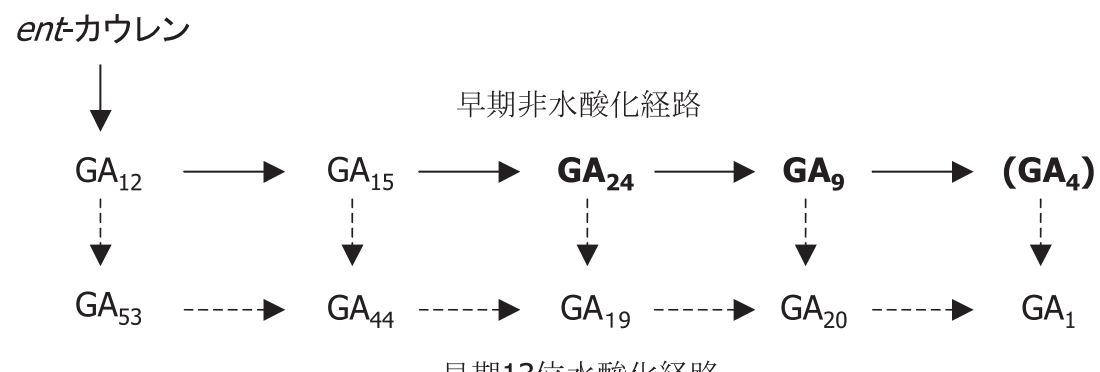

第 3 図 植物に打ける一般的な内生ジベレリン生合成経路（実線矢印扣よび破線矢印）とシネンシス系デルフィニウムのシュー 卜に打いて推定される生合成経路（実線矢印）

太字 : シネンシス系デルフィニウムのシュートから同定された内生 GA

（）内：同定には至らなかったが，極微量の存在が確認された内生 GA

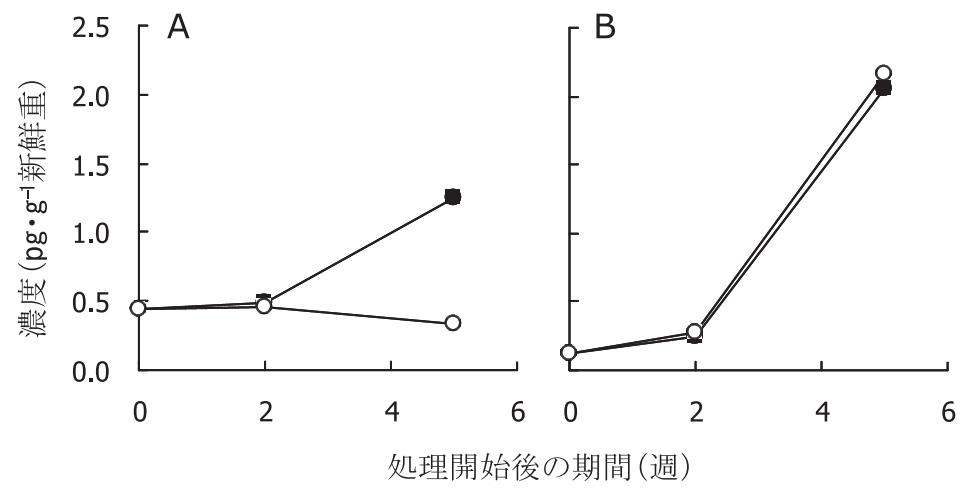

第 4 図 DIF 処理後のシネンシス系デルフィニウムのシュートに含まれる内生 GA 濃度の推移

$\mathrm{A}: \mathrm{GA}_{24}$ 濃度, $\mathrm{B}: \mathrm{GA}_{9}$ 濃度

: +DIF, $\bigcirc:-$ DIF, 処理条件は第 1 図を参照

(第 4 表)。これらの GA は早期非水酸化経路に属し，活性 型 $\mathrm{GA}$ である $\mathrm{GA}_{4}$ の前駆体である（第 3 図）。定性分析の 際，フルスキャンモードによる GC/MS クロマトグラフで は，夾雑物の影響から $\mathrm{GA}_{4}$ を同定できなかったが， $\mathrm{SIM}$ (Selected Ion Monitoring) モードでは, $\mathrm{GA}_{4}$ に相当するピー クが不十分ながら検出され, 極微量の $\mathrm{GA}_{4}$ の存在が確認さ れた。

DIF 処理後の内生 $\mathrm{GA}$ 濃度の推移についてみると, $\mathrm{GA}_{24}$ 濃度は+DIF で処理期間の進行に伴い増加したが，-DIF で は減少した (第 4 図). $\mathrm{GA}_{9}$ 濃度は+DIF，-DIF ともに，処 理期間の進行に伴い同様に増加した。

\section{考察}

本研究結果から, -DIF 処理によりシネンシス系デルフィ
ニウムの草丈を短縮できることが明らかにされた．このこ とは，カンパニュラなどの報告 (Berghage ら, 1990; Erwin ら， 1991; Erwin ら, 1994; Karlsson ら, 1989; Moe, 1990; Moe • Heins, 1990; Moe ら，1991）と一致した. しかし，-DIF は，昼温よりも夜温を高く設定するため，実用面ではコス トの問題が生ずることが考えられる。 そこで，より実用性 が高いと考えられる短時間変温を行った結果，TDでは草 丈短縮は生じず，逆に TR では草丈短縮を確認した，従っ て，一DIF に打けるシネンシス系デルフィニウムの草丈短 縮，すなわち茎伸長抑制は，明期の低温の影響によるので はなく，暗期開始時の高温によるものと推察された。

DIF および短時間変温の効果については, 多くの花き類 で報告されており，DIF 処理で効果があるが，短時間変温 では効果が小さいか，ないものも認められている（腰岡・ 
Moe，1999). ベゴニアでの草丈は，-DIF と TR で短縮する が，TD では短縮しないこと（Mortensen・Moe, 1992），また， ペチュニアの草丈の短縮程度は，TR で大きく, TD で小さ いが，この効果には品種間差があること（Mortensen・Moe, 1992）などが報告されている，従って，DIF や短時間変温 に対する反応は，植物種や品種により差異があり，シネン シス系デルフィニウムは，ベゴニアと類似の反応を示すと 考えられた.

DIF あるいは短時間变温の茎伸長に対する影響に関して は, 植物ホルモンとの関連, 特に内生 GAの関与について の研究が多くなされている. カンパニュラにおいて, -DIF によって茎伸長を抑制された植物が， $\mathrm{GA}_{3}$ 処理により伸長 を回復したこと（Moe, 1990），また-DIF による茥伸長抑制 とともに, 内生 GA 濃度が減少したこと（Jensen ら， 1996） が報告されている，本研究では，-DIFによる茥伸長抑制に 伴い, 早期非水酸化経路に打いて, 活性型 $\mathrm{GA}\left(\mathrm{GA}_{4}\right)$ の前駆 体である $\mathrm{GA}_{24}$ の濃度は減少したが， $\mathrm{GA}_{9}$ は減少しなかっ た. Nishijima ら（1997）も，キクに执いて，TDによる茎伸 長抑制とともに，活性型である $\mathrm{GA}_{1}$ と早期 13 位水酸化経 路で生合成上 $\mathrm{GA}_{24}$ に相当する $\mathrm{GA}_{19}$ の濃度は減少したが, $\mathrm{GA}_{9}$ に相当する $\mathrm{GA}_{20}$ はほとんど減少しないことを報告し ている，従って，本実験結果とキクの茥伸長抑制に伴う内 生 GA 濃度の変動には共通性が認められ, シネンシス系デ ルフィニウムにおいても DIF の日周温度による草丈制御に 内生 GA が関わることが示唆された。

本研究に打いて，茥の髄細胞の大きさと数を比較した結 果, -DIF では細胞が小型化するだけでなく, 数も減少して いた．従って，-DIF は細胞伸長だけでなく，細胞分裂をも 抑制すると判断された。 これに対してテッポウユリでは, DIF は細胞分裂ではなく，細胞伸長に影響することが報告 されている (Erwin ら，1994）。このとから, 組織細胞レ ベルでの DIF の影響は, 植物種により異なることが考えら れる. またダイコン胚軸部の内生 IAA レベルが DIFによっ て変化することが報告されて抢り（Hayata ら，2001）, DIF は GA 以外の植物ホルモン代謝にも関与している可能性が 推察される. 細胞分裂にはオーキシンとサイトカイニンが 関わることが一般に知られて扣り，本実験で確認された一 DIF での細胞数の減少は，これらの植物ホルモン代謝を介 して生じている可能性も考えられる.

日周温度の実用性に関しては，本研究結果から，シネン シス系デルフィニウムは TR 処理によって, 主花穂の小花 数，側枝数および開花期を变化させずに，草丈を短縮でき ることが示された．暗期開始時の TR の具体的方法として は，日没前の施設の密閉処理，および暖房機や温床マット 使用による一時的な昇温が想定される. 今後，実際の栽培 時期に即して，処理温度，処理時間および昇温方法などを 詳細に検討することにより，有用な草丈制御技術としての 利用が期待される.

\section{摘 要}

DIF（昼夜温度差），TD（短時間降温）および TR（短時間 昇温）がシネンシス系デルフィニウム‘ブルーミラーの 生育に及ぼす影響について調査した。草丈は，-DIF（暗期 よりも明期の温度が低い）により，+DIF（暗期よりも明期 の温度が高い） に比べ $42 \sim 49 \%$ 減少した. 明期開始前後 4 時間, $10^{\circ} \mathrm{C}$ の $\mathrm{TD}$ は，草丈に影響しなかった。一方，暗 期開始後 4 時間, $30^{\circ} \mathrm{C}$ の TR は， +DIF に比べ草丈を 22 $33 \%$ 減少させた。 -DIF 処理した茎の髄細胞の長径と短径 は，いずれも+DIF に比べ約 $20 \%$ 減少した．髄細胞数は， 垂直方向で + DIF に比べ 26\%減少したのに対して，水平方 向での減少は $5 \%$ にすぎなかった. シネンシス系デルフィ ニウムのシュートに打ける内生 $\mathrm{GA}$ として, $\mathrm{GA}_{9}$ と $\mathrm{GA}_{24}$ が 同定された. $\mathrm{GA}_{24}$ 濃度は, -DIF では+DIF よりも低く, DIF はジベレリン代謝を介して茥伸長を制御していることが示 唆された。

\section{引用文献}

Berghage, R. D., J. A. Flore, R. D. Heins and J. E. Erwin. 1990. The relationship between day and night temperature influences photosynthesis but not light compensation point or flower longevity of easter lily, Lilium longiflorum Thunb. Acta Hort. 272: 91-95.

Erwin, J. E., R. D. Heins and R. Moe. 1991. Temperature and photoperiod effects on Fuchsia $\times$ hybrida morphology. J. Amer. Soc. Hort. Sci. 116: 955-960.

Erwin, J., P. Velguth and R. Heins. 1994. Day/night temperature environment affects cell elongation but not division in Lilium longiflorum Thunb. J. Exp. Bot. 45: 1019-1025.

Hayata, Y., K. Kotani and X. X. Li. 2001. Effects of day and night temperatures on hypocotyl elongation and endogenous levels of indole-3-acetic and abscisic acids in radish (Raphaus sativus L.). J. Japan. Soc. Hort. Sci. 70: 443-447.

Jensen, E., S. Eilertsen, A. Ernsten, O. Juntilla and R. Moe. 1996 Thermoperiodic control of stem elongation and endogenous gibberellins in Campanula isophylla. J. Plant Growth Regul. 15: 167-171.

Karlsson, M. G., R. D. Heins, J. E. Erwin, R. D. Berghage, W. H. Carlson and J. A. Biernbaum. 1989. Temperature and photosynthetic photon flux influence chrysathemum shoot development and flower initiation under short-day conditions. J. Amer. Soc. Hort. Sci. 114: 158-163.

勝谷範敏・池田好伸. 1997. デルフィニウムの開花特性に 関する研究. 園学雑. 66: 121-131.

腰岡政二・R. Moe. 1999. 施設園芸作物の形態に及ぼす温. 度周期の影響. 植物の化学調節. 34: 66-74.

Moe, R. 1990. Effect of day and night temperature alternations and of plant growth regulators on stem elongation and 
flowering of the long-day plant Campanula isophylla Moretti. Scientia Hortic. 43: 291-305.

Moe, R. and R. Heins. 1990. Control of plant morphogenesis and flowering by light quality and temperature. Acta Hort. 272: 81-89.

Moe, R., R. D. Heins and J. Erwin. 1991. Stem elongation and flowering of the long-day plant Campanula isophylla Moretti in response to day and night temperature alternations and light quality. Scientia Hortic. 48: 141-151.

Mortensen, L. M. and R. Moe. 1992. Effects of various day and night temperature treatments on the morphogenesis and growth of some greenhouse and bedding plant species. Acta Hort. 327: 77-86.

西島隆明. 2000 . ダイコンの花成・抽苔の調節機構とその 制御. 野菜茶試研報. 15: 135-208.

Nishijima, T., M. Nonaka, M. Koshioka, H. Ikeda, M. Douzono, H. Yamazaki and L. N. Mander. 1997. Role of gibberellins in the thermoperiodic regulation of stem elongation in Dendranthema grandiflorum Tzvelev. Biosci. Biotech. Biochem. 61: 1362-1366. 